\title{
Increased Leptin/Leptin Receptor Pathway Affects Systemic and Airway Inflammation in COPD Former Smokers [Retraction]
}

\author{
Bruno A, Alessi M, Soresi S, et al. J Inflamm Res. \\ 2011;4:51-59.
}

The Editor and Publisher of Journal of Inflammation Research wish to retract the published article. Concerns were raised regarding the duplication of images in Figure 3 describing leptin receptor expression with those from an article published by the authors several years previously describing muscarinic receptor expression. Specifically:

- Figure 3A, Leptin receptor expression, Smokers, appears to have been duplicated with Figure 2 panel M3 COPD, for the expression of muscarinic receptors.

- Figure 3D, Leptin expression, Smokers, appears to have been duplicated with Figure 2 panel M1

\author{
Smokers, for the expression of muscarinic \\ receptors. \\ - Figure 3A, Leptin receptor expression, Smokers, \\ appears to share duplicated elements with Figure 3D, \\ Leptin expression, Smokers.
}

The authors did not respond to our queries and the Editor advised for the article to be retracted.

Our decision-making was informed by our policy on publishing ethics and integrity and the COPE guidelines on retraction.

The retracted article will remain online to maintain the scholarly record, but it will be digitally watermarked on each page as "Retracted".

\section{Publish your work in this journal}

The Journal of Inflammation Research is an international, peerreviewed open-access journal that welcomes laboratory and clinical findings on the molecular basis, cell biology and pharmacology of inflammation including original research, reviews, symposium reports, hypothesis formation and commentaries on: acute/chronic inflammation; mediators of inflammation; cellular processes; molecular mechanisms; pharmacology and novel anti-inflammatory drugs; clinical conditions involving inflammation. The manuscript management system is completely online and includes a very quick and fair peerreview system. Visit http://www.dovepress.com/testimonials.php to read real quotes from published authors. 